\title{
Inventarisasi Emisi Gas Rumah Kaca Sektor Limbah Dengan First Order Decay Di Kabupaten Karangasem
}

\author{
Inventory of Greenhouse Gas Emissions in the Waste Sector with First Order Decay in \\ Karangasem Regency
}

\author{
Affan Irfan Fauziawan * \\ Program Studi Sistem Informasi \\ Fakultas Informatika dan Komputer, Institut Teknologi dan Bisnis STIKOM, Bali \\ Jl. Raya Puputan No 86 - Renon - Denpasar - Bali
}

\section{Artikel histori : \\ Diterima 23 Februari2021 Diterima dalam revisi 26 April 2021 Diterima 3 Mei 2021 Online 3 Mei 2021}

\begin{abstract}
ABSTRAK: Produksi limbah meningkat seiring dengan meningkatnya jumlah penduduk, tingkat urbanisasi dan pendapatan masyarakat. Sampah merupakan salah satu penyumbang emisi gas rumah kaca (GRK) yang dapat menyebabkan adanya pemanasan global (global warming). Pemerintah Indonesia masih berkomitmen untuk dapat menurunkan emisi gas rumah kaca dan berupaya untuk mengurangi/membatasi peningkatan suhu dibawah $1,5{ }^{\circ} \mathrm{C}$. Kabupaten Karangasem, berada di Pulau Bali, dengan jumlah penduduk pada tahun 2018 adalah 414.800 jiwa. Jumlah penduduk tersebut tersebar dalam 8 kecamatan dengan angka pertambahan penduduk di Karangasem rata-rata $0,88 \%$ per tahun. Sebaran jumlah penduduk akan berbanding lurus dengan sebaran limbah padat yang dihasilkan. Inventarisasi emisi GRK penting dilakukan untuk mengetahui jumlah emisi yang ada di Kabupaten Karangasem. Metode penghitungan limbah padat kota akan dilakukan dengan menggunakan metode First Order Decay yang terdapat pada IPCC (Intergovernmental Panel on Climate Change) Guidelines. Dari hasil perhitungan telah didapatkan emisi GRK di tiap-tiap kecamatan yang ada di Kabupaten Karangasem. Total emisi GRK pada tahun 2019 yaitu sebesar 11.764 ton $\mathrm{CO}_{2}$-e, dengan penyumbang emisi GRK tertinggi yaitu Kecamatan Karangasem sebesar 2.302 ton $\mathrm{CO}_{2}$-e dan yang terendah yaitu kecamatan Sidemen sebesar 894 ton $\mathrm{CO}_{2}$-e. Dengan adanya penelitian ini, diharapkan para stakeholder mampu membuat usaha (mitigasi) yang dapat menurunkan emisi GRK tersebut.
\end{abstract}

Kata Kunci: Limbah, Emisi, Gas Rumah Kaca, First Order Decay, IPCC.

ABSTRACT: Waste production increases with the increase in population, urbanization rate and people's income. Garbage is a contributor to greenhouse gas (GHG) emissions which can cause global warming. The Indonesian government is still committed to reducing greenhouse gas emissions and working to reduce / limit the increase in temperature below 1.50C. Karangasem Regency, is on the island of Bali, with a population in 2018 of 414,800 people. The population is spread across 8 sub-districts with the population growth rate in Karangasem averaging $0.88 \%$ per year. The distribution of the population will be directly proportional to the distribution of solid waste produced. It is important to do an inventory of GHG emissions to determine the amount of emissions in Karangasem Regency. The method for calculating municipal solid waste will be carried out using the First Order Decay method contained in the IPCC (Intergovernmental Panel on Climate Change) Guidelines. From the calculation results, GHG emissions have been obtained in each sub-district in Karangasem Regency. Total GHG emissions in 2019 amounted to 11,764 tons $\mathrm{CO} 2-\mathrm{e}$, with the highest GHG emission contributor, namely Karangasem District with 2,302 tons CO2-e and the lowest being Sidemen District with 894 tons CO2-e. With this research, it is hoped that stakeholders will be able to make efforts (mitigation) that can reduce these GHG emissions. .

Keywords: : Waste, Emission, Green House Gases, First Order Decay, IPCC

\section{Pendahuluan}

Perubahan iklim telah menjadi persoalan global dan untuk mengatasinya melibatkan berbagai negara dan berbagai disiplin ilmu. Perubahan iklim mempengaruhi berbagai aspek kehidupan, antara lain aspek lingkungan, aspek sosial ekonomi, aspek kesehatan, serta aspek lainnya. Perubahan iklim merupakan salah satu dampak dari adanya Gas Rumah Kaca (GRK), dimana dapat menyebabkan presipitasi meningkat sampai $50 \%$ bahkan lebih sehingga 
meningkatkan potensi terjadinya banjir. (Elizbarashvili, dkk., 2017). Pemerintah Indonesia terus berkomitmen untuk terus dapat menurunkan emisi GRK. Walaupun secara teknis kenaikan suhu di tingkat $1.5^{\circ} \mathrm{C}$ dapat dengan mudah dihindari, diperlukan perubahan perilaku dan teknologi secara menyeluruh untuk mencapai pengurangan emisi tersebut. Kabupaten Karangasem, merupakan daerah yang berada di belahan timur Pulau Bali, yang secara administratif merupakan salah satu kabupaten dalam wilayah Provinsi Bali. Jumlah penduduk Kabupaten Karangasem pada tahun 2019 berdasarkan hasil proyeksi sebaran penduduk tiap kecamatan adalah 414.800 jiwa. Angka pertambahan penduduk di Karangasem rata-rata 0,88\% per tahun. (Badan Pusat Statistik, 2019). Pertambahan penduduk tersebut membawa konsekuensi logis terhadap meningkatnya jumlah sampah yang dihasilkan. Hal itulah yang melatarbelakangi instansi terkait untuk tetap fokus pada pengelolaan limbah padat (sampah), diantaranya yaitu pengembangan sarana Tempat Pembuangan Akhir (TPA) sampah Linggasana. Dengan mengetahui emisi yang dihasilkan, maka tidak tertutup kemungkinan untuk menarik investor dalam pengelolaan emisi tersebut menjadi energi yang bermanfaat bagi masyarakat Karangasem, yaitu dengan mengubah gas penghasil emisi tersebut (methane) menjadi energi listrik.

Gas rumah kaca merupakan gas-gas yang ada di atmosfer yang menyebabkan efek rumah kaca, yang dapat ditimbulkan akibat aktivitas manusia. Dalam troposfer terdapat gas-gas rumah kaca yang menyebabkan pemanasan global (global warming). Perubahan iklim dapat disebabkan secara langsung ataupun tidak langsung oleh kegiatan manusia yang mengubah komposisi atmosfer sehingga mempengaruhi varibialitas iklim alami yang diamati selama periode tertentu. Istilah gas rumah kaca disampaikan para ahli dalam menggambarkan fungsi atmosfer bumi. Tanpa atmosfer, bumi akan dingin. Hal ini terjadi karena adanya keberadaan gas-gas di atmosfer yang mampu menyerap dan memancarkan kembali radiasi inframerah.

Menurut Konvensi Kerja Perserikatan Bangsa-Bangsa tentang Perubahan Iklim (United Nation Framework Convention on Climate Change/UNFCCC), sistem iklim dalam hubungannya dengan perubahan iklim didefinisikan sebagai totalitas atmosfer, hidrosfer, biosfer, dan geosfer dengan interaksinya. Sedangkan perubahan iklim dinyatakan sebagai perubahan iklim yang dipengaruhi langsung atau tidak langsung oleh aktivitas manusia yang mengubah komposisi atmosfer, yang akan memperbesar keragaman iklim teramati pada periode yang cukup panjang. Perubahan iklim terutama disebabkan oleh meningkatnya konsentrasi $\mathrm{CO}_{2}$ dan GRK lainnya. Meningkatnya konsentrasi $\mathrm{CO}_{2}$ dan GRK lainnya tersebut diketahui merupakan akibat dari sejumlah aktivitas antropogenik, terutama akibat dari pembakaran bahan bakar fosil dalam produksi energi dan kegiatan alih guna lahan. Pemerintah daerah juga aktif untuk mensosialisasikan pentingnya menjaga lingkungan seperti tidak membuang sampah sembarangan, membakar sampah sembarangan, dan lainlain. Penghitungan jumlah sampah yang dihasilkan di tiap daerah penting untuk dilakukan. Hal inilah yang disebut dengan inventarisasi emisi GRK dari sektor limbah. Dari jumlah sampah yang dihasilkan tiap daerah akan digunakan untuk menghitung emisi GRK yang disebabkan oleh sampah yang masuk ke TPA. Data yang diperoleh digunakan untuk memprediksi tren emisi untuk masa depan. Sehingga dengan melihat tren emisi GRK tersebut, pemerintah daerah akan memperoleh gambaran untuk mengambil langkah-langkah untuk menurunkan emisi GRK dari sektor limbah tersebut. Respon yang dilakukan pemerintah Indonesia di dalam menanggapi isu perubahan iklim dan pemanasan global tertuang dalam Peraturan Presiden Nomor 61 Tahun 2011 tentang Rencana Aksi Nasional Penurunan Emisi Gas Rumah Kaca (RAN-GRK). Pada Perpres tersebut terdapat komitmen pemerintah Indonesia untuk menurunkan emisi GRK sebesar $26 \%$ dari Business as Usual (BaU) pada tahun 2020. RAN-GRK yang diprogramkan oleh pemerintah merupakan gabungan dari RAD-GRK (Rencana Aksi Daerah Penurunan Emisi Gas Rumah Kaca).

Penelitian ini menjadi penting untuk dibahas karena hal tersebut tertuang dalam Peraturan Presiden No. 71 Tahun 2011 tentang Penyelenggaraan Inventarisasi Emisi GRK Nasional. Pada penelitian ini akan dihitung besarnya estimasi emisi GRK dari sektor limbah (sampah). Berdasarkan Intergovernmental Panel on Climate Change (IPCC) 2006, sumber emisi GRK pengolahan limbah mencakup:

i. Tempat Pembuangan Akhir (TPA) limbah padat atau Solid Waste Disposal Site (SWDS).

ii. Unit pengolahan limbah padat secara biologi (pengomposan dan fasilitas biogas).

iii. Incinerator dan unit pembakaran limbah padat secara terbuka.

iv. Unit pengolahan limbah clinical waste dan hazardous waste. (Barrera dan Hooda, 2016).

Pada penelitian ini akan dilakukan inventarisasi GRK sektor limbah padat di TPA. Inventarisasi GRK ini perlu dilakukan, untuk mengetahui besarnya emisi GRK yang dihasilkan dari sektor tersebut. Limbah padat yang umumnya dibuang di TPA/SWDS adalah sampah padat domestik (sampah kota) atau municipal solid waste (MSW) dari rumah tangga, komersial, kantor, pasar, industri. MSW stream yang bersumber dari kegiatan domestik di Rumah Tangga, perkantoran, pasar, sektor komersial (mall, pertokoan, restoran, hotel, dll), dan industri umumnya dibawa ke TPS lalu ke TPA. Di TPS limbah padat-limbah padat tersebut dapat bercampur satu sama lain sebelum dibawa ke TPA. Sebagian besar adalah sampah organik (50 $-80 \%$ ) yang didominasi oleh sampah makanan (Meidiana \& Gamse, 2010). Sedangkan komponen limbah padat yang memiliki nilai ekonomi tinggi akan diambil oleh pemulung mulai sumbernya maupun di TPS dan di TPA. Beberapa sampah nonorganik yang masih memiliki nilai untuk dijual diantaranya yaitu sampah plastik, logam dan kertas/kardus. Para pengumpul sampah ini kemudian menjual ke tengkulak yang lebih besar. Biasanya komponen sampah ini akan di daur ulang untuk menghasilkan barang yang bisa dipakai kembali. Bahkan untuk komponen sampah jenis logam, 
kadang-kadang untuk ekspor, terutama ke Cina (MacRae \& Rodic, 2013). Merujuk IPCC 2006, jenis-jenis limbah padat (sampah) yaitu: sampah makanan, sampah kebun/ taman, kayu, kertas dan karton, tekstil, nappies, karet dan kulit, plastik, logam, gelas/keramik, lain-lain (abu, debu, dll). Dari jenis-jenis sampah tersebut, yang memiliki nilai DOC (Degradable Organic Carbon) di TPA (landfill) yaitu jenis sampah makanan, sampah kebun/ taman, kayu, kertas dan karton, tekstil, nappies. (Eggleston, H.S., and Tanabe, K., 2006).

\section{Metode Penelitian}

\subsection{Model Konseptual Penelitian}

Penghitungan emisi GRK untuk inventarisasi GRK, pada dasarnya dasarnya merujuk pendekatan umum sebagaimana disampaikan pada persamaan berikut:

Emisi GRK = Data Aktivitas $\mathrm{x}$ Faktor Emisi

Data Aktivitas (DA): besaran kuantitatif kegiatan manusia (anthropogenic) yang melepaskan GRK. Pada pengolahan limbah, DA adalah masa limbah yang diolah setiap jenis unit pengolahan dan direpresentasikan sebagai waste generation (laju pembentukan limbah).

Faktor Emisi: faktor yang menunjukkan intensitas emisi GRK per unit aktivitas yang besarnya bergantung kepada karakteristik limbah dan sistem pengolahan limbah. (Ebie, dkk., 2014).

\subsection{Metodologi Perhitungan Emisi GRK Limbah Padat di TPA}

Berdasarkan metode First Order Decay, total emisi gas $\mathrm{CH}_{4}$ pada tahun $\mathrm{T}$ adalah total gas $\mathrm{CH}_{4}$ yang terbentuk pada tahun $\mathrm{T}$ dikoreksi dengan besarnya gas $\mathrm{CH}_{4}$ yang di-recovery untuk dimanfaatkan atau dibakar untuk keamanaan. (Zurbrugg C dkk, 2012)

$$
\text { Emisi }=\left[\sum_{\mathrm{x}} \mathrm{CH}_{4} \text { generated }_{\mathrm{x}, \mathrm{T}}-\mathrm{R}_{\mathrm{T}}\right] \cdot\left(1-\mathrm{OX}_{\mathrm{T}}\right)
$$

Di mana:

$\mathrm{T}=$ tahun inventarisasi

$\mathrm{X} \quad=$ tipe atau jenis limbah

$\mathrm{R}_{\mathrm{T}} \quad=\mathrm{CH}_{4}$ yang di-recovery untuk dimanfaatkan atau dibakar pada tahun T, Ggram

$\mathrm{OX}_{\mathrm{T}} \quad=$ faktor oksidasi pada tahun $\mathrm{T}$, fraksi

$\mathrm{CH}_{4}$ generated $_{x, T}=\mathrm{CH}_{4}$ yang terbentuk pada tahun $\mathrm{T}$ hasil dekomposisi komponen organik jenis tertentu (x) yang tersimpan di dalam limbah padat (Degradable Organic Carbon/DOC).

Emisi $\mathrm{CH}_{4}$, tahun $\mathrm{T}=\mathrm{CH}_{4}$ yang diemisikan dari limbah padat di TPA untuk satu tahun. Besarnya $\mathrm{CH}_{4}$ generated $_{x, T}$ dipengaruhi parameter-parameter sebagai berikut:

- DOC $_{\mathrm{i}}$, yaitu besarnya DOC spesifik untuk setiap komponen limbah padat.

- $\mathrm{DOC}_{\mathrm{f}}$, yaitu fraksi DOC yang terdisimilasi dalam kondisi anaerobik.
- Iklim regional lokasi TPA, menentukan waktu paruh $\left(\mathrm{t}_{1 / 2}\right)$ dan konstanta laju pembusukan limbah padat $(\mathrm{k})$

- Waktu paruh( $\left.\mathrm{t}_{1 / 2}\right)$, yaitu waktu yang diperlukan limbah padat untuk terdekomposisi menjadi $\mathrm{CH}_{4}$, yang tergantung pada jenis iklim suatu wilayah dan tiap jenis komponen limbah padat

- Konstanta laju pembusukan limbah padat atau laju pembentukan gas metana, yaitu:

$\mathrm{k}=\ln (2) / \mathrm{t}_{1 / 2}$

- OX, yaitu faktor oksidasi.

- Waktu delay, yaitu waktu tenggat sebelum dimulainya reaksi pembusukan limbah padat.

\subsection{Teknik Pengumpulan Data}

Jenis data yang didapat dari hasil survey langsung ke lapangan yaitu jumlah sampah yang masuk ke TPA Linggasana. Pengolahan limbah padat (sampah) di TPA Kab. Karangasem merupakan TPA tipe open dumping. TPA Kab. Karangasem juga tidak memiliki jembatan timbang, sehingga data kendaraan yang berisikan sampah dan sumber sampah perlu dicatat. Basis perhitungan volume adalah kapasitas (volume) kendaraan (berdasarkan spesifikasi) dan persentase volume aktual berdasarkan pengamatan visual (misal: 75\% dari kapasitas, 125\% dari kapasitas). Konversi data volume menjadi data berat sampah menggunakan persamaan dan faktor konversi (bulk density sampah).

\section{Bulk Density = (hasil rata-rata berat sampah:volume sampah yang masuk TPA)}

Pada awal tahun 2020, jembatan timbang untuk menimbang jumlah sampah yang masuk ke TPA selesai dibuat. Akan tetapi data yang dipakai pada penelitian ini belum memakai data jembatan timbangan, karena baru beroperasi.

\subsection{Geographic Information System (GIS)}

Sistem Informasi Geografis merupakan sebuah konsep yang terdiri dari sistem informasi yang didapatkan dari pengolahan data studi tentang geografis (permukaan bumi). Konsep ini selanjutnya mengimplementasikan sistem informasi geografis dalam bentuk peta digital. Sistem Informasi Geografis juga dapat didefinisikan sebagai sistem informasi yang dapat menganalisis, menyimpan, memperbaharui, mengintegrasikan dan menampilkan segala bentuk informasi yang berkaitan dengan permukaan bumi. Dengan adanya sistem informasi geografis ini diharapkan dapat mengelola data yang kompleks dan terstruktur dengan baik, sehingga membantu para stakeholder dalam mengambil keputusan. (Supuwiningsih, dkk. 2018).

\section{Hasil dan Pembahasan}

Berdasarkan hasil survey yang dilakukan ke Dinas Lingkungan Hidup dan Dinas Pekerjaan Umum dan Perumahan Rakyat Kabupaten Karangasem, diperoleh hasil bahwa masyarakat Kabupaten Karangasem tidak semuanya membuang sampah di TPS ataupun ke TPA. Ada perilaku 
masyarakat yang membuang sampah dengan cara dibakar, ditimbun dan dibuang pada tempat tertentu. Sedangkan jumlah sampah yang terangkut ke TPA dari tahun 2014 sampai dengan tahun 2019 dapat dilihat pada Tabel 1:

\begin{tabular}{cc}
\multicolumn{2}{c}{ Tabel. 1 Volume sampah terangkut ke TPA } \\
\hline Tahun & Volume Sampah $\left(\mathbf{m}^{\mathbf{3}}\right)$ \\
\hline 2014 & 42.786 \\
2015 & 43.212 \\
2016 & 43.467 \\
2017 & 44.885 \\
2018 & 46.637 \\
2019 & 47.536 \\
\hline
\end{tabular}

(Dinas Lingkungan Hidup Kabupaten Karangasem., 2019)

Untuk perhitungan inventarisasi emisi GRK, data volume tersebut akan dikonversikan terlebih dahulu menjadi satuan berat (ton). Diketahui, untuk densitas sampah nasional adalah $347 \mathrm{~kg} / \mathrm{m}^{3}$. (Kementerian Lingkungan Hidup, 2012).

Contoh: Dengan menggunakan data tahun 2014, diketahui volume sampah adalah $42.786 \mathrm{~m}^{3}$.

$$
W(\text { ton })=\frac{42786 \mathrm{~m}^{3} \times 347^{\mathrm{kg} / \mathrm{m}^{3}}}{1000}=14.847 \mathrm{ton}
$$

Dengan cara yang sama, maka didapatkan data berat sampah yang masuk ke TPA Kab. Karangasem sebagaimana ditunjukkan pada Tabel 2:

Tabel. 2 Berat sampah yang masuk ke TPA

\begin{tabular}{ccc}
\hline Tahun & Volume Sampah $\left.\mathbf{( m}^{\mathbf{3}}\right)$ & Berat (ton) \\
\hline 2014 & 42.786 & 14.847 \\
2015 & 43.212 & 14.995 \\
2016 & 43.467 & 15.083 \\
2017 & 44.885 & 15.575 \\
2018 & 46.637 & 16.183 \\
2019 & 47.536 & 16.495 \\
\hline
\end{tabular}

Dari Tabel 2 di atas bisa dilihat bahwa setiap tahun, jumlah sampah yang dihasilkan semakin meningkat.

MSW activity data

Help and default regional values are given in the 2006 IPCC Guidelines.

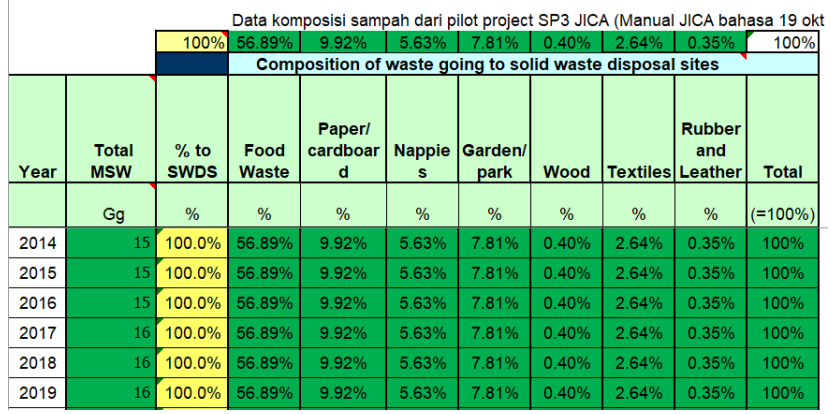

Gambar 1. Activity Program Penghitungan Emisi GRK

Faktor-faktor yang berpengaruh dalam penghitungan inventarisasi GRK di antaranya adalah komposisi limbah padat dan kandungan bahan kering (dry matter content). Pada penelitian ini data komposisi limbah padat dan kandungan bahan kering (dry matter content) menggunakan angka default IPCC2006 dan angka hasil survey pada pilot project Kementerian Lingkungan Hidup.

Perhitungan emisi GRK menggunakan persamaan dasar data aktivitas dan faktor emisi yang sudah dikembangkan di IPCC Guidelines sebagaimana ditunjukkan pada Gambar 1, menjadi sebuah program/sistem penghitungan Emisi GRK sektor limbah padat (Gambar 2).

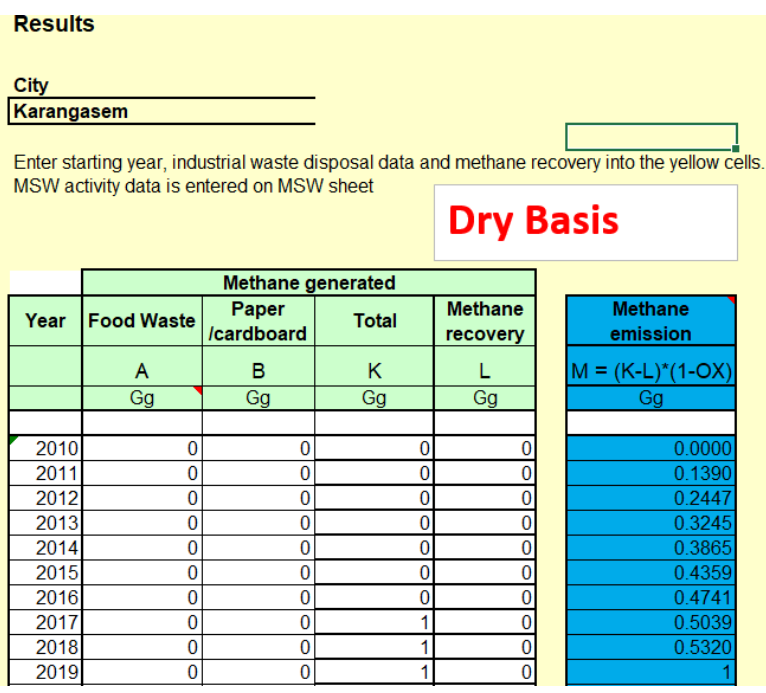

Gambar 2. Results Penghitungan Emisi GRK

Contoh: Tahun 2014

Dari hasil perhitungan didapatkan emisi GRK (Gigagram Methana) yang dihasilkan adalah sebesar $0,3870 \mathrm{Gg}$. Satuan Gigagram $(\mathrm{Gg})$ kemudian di konversikan menjadi = $(0,3870) \mathrm{Gg} \times 1000=387$ ton $\mathrm{CH}_{4}$.

Dengan cara yang sama, maka akan didapatkan hasil yang ditunjukkan pada Tabel 3:

Tabel. 3 Emisi yang dihasilkan (ton $\mathrm{CH}_{4}$ )

\begin{tabular}{cc}
\hline Tahun & $\begin{array}{c}\text { Emisi GRK yang dihasilkan } \\
\text { (ton CH4) }\end{array}$ \\
\hline 2014 & 387 \\
2015 & 436 \\
2016 & 474 \\
2017 & 504 \\
2018 & 532 \\
2019 & 560 \\
\hline
\end{tabular}

Kemudian data tersebut dikonversikan menjadi satuan ton $\mathrm{CO}_{2}$-e di mana menurut rekomendasi dari UNFCCC nilai potensi pemanasan global, besarnya 1 methane sama dengan 21-25 kali karbondioksida. Dalam penelitian ini diasumsikan nilai $1 \mathrm{CH}_{4}$ sama dengan 21 kali nilai $\mathrm{CO}_{2}$, maka didapatkan emisi GRK sebagaimana ditunjukkan pada Tabel 4 
Tabel. 4 Emisi yang dihasilkan (ton $\mathrm{CO}_{2}-\mathrm{e}$ )

\begin{tabular}{cc}
\hline Tahun & $\begin{array}{c}\text { Emisi GRK yang dihasilkan } \\
\text { (ton } \mathrm{CO}_{2} \text {-e) }\end{array}$ \\
\hline 2014 & 8.117 \\
2015 & 9.153 \\
2016 & 9.956 \\
2017 & 10.582 \\
2018 & 11.173 \\
2019 & 11.764 \\
\hline
\end{tabular}

Grafik emisi yang dihasilkan TPA Kab. Karangasem ditunjukkan pada Gambar 3:

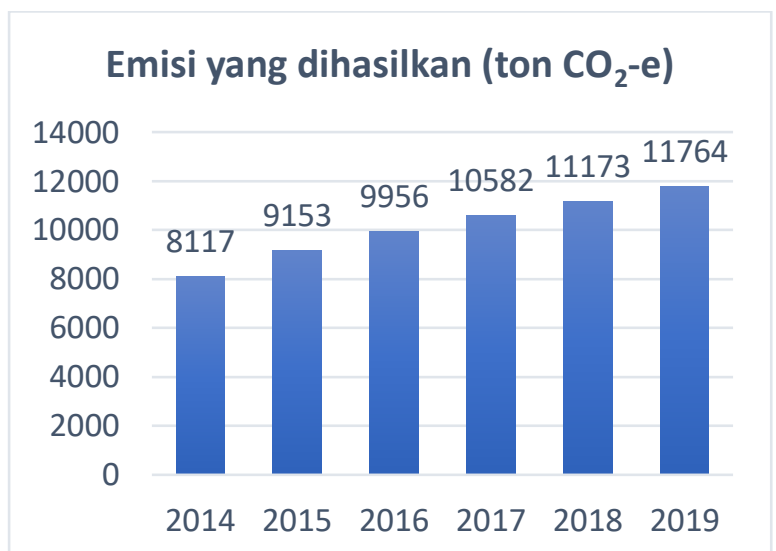

Gambar 3. Grafik emisi yang dihasilkan TPA Karangasem

Tahapan berikutnya dari penelitian ini adalah untuk melakukan pemetaan dengan menggunakan metode Geographic Information System (GIS). Pada tahapan ini akan dilakukan pemetaan emisi GRK yang dihasilkan di tiap-tiap kecamatan yang ada di Kabupaten Karangasem. Dari data emisi GRK yang dihasilkan tiap tahun, kecenderungannya adalah semakin naik. Untuk membuat pemetaan akan digunakan data terakhir yaitu data tahun 2019. Dari hasil perhitungan diperoleh untuk emisi GRK dari sektor limbah di Kabupaten Karangasem sebesar 11.764 ton $\mathrm{CO}_{2}$-e. Dengan persentase jumlah timbulan per kecamatan sudah didapatkan, maka emisi GRK per kecamatan pada tahun 2019 adalah sebagai berikut: (Supuwiningsih, N.N., 2016)

Tabel. 5 Emisi GRK tiap kecamatan tahun 2019

\begin{tabular}{ccccr}
\hline No & Kecamatan & $\begin{array}{c}\text { Timbulan } \\
\text { Sampah } \\
\left(\mathrm{m}^{3} / \text { hari }\right)\end{array}$ & $\%$ & $\begin{array}{r}\text { Emisi GRK } \\
\text { (ton CO2-e) }\end{array}$ \\
\hline 1 & Rendang & 74,44 & 7,80 & 917,24 \\
2 & Sidemen & 72,57 & 7,60 & 894,20 \\
3 & Manggis & 112,56 & 11,79 & $1.386,95$ \\
4 & Karangasem & 186,84 & 19,57 & $2.302,21$ \\
5 & Abang & 156,55 & 16,40 & $1.928,99$ \\
6 & Bebandem & 107,84 & 11,30 & $1.328,79$ \\
7 & Selat & 83,43 & 8,74 & $1.028,01$ \\
8 & Kubu & 160,47 & 16,81 & $1.977,29$ \\
\hline & Total & 954,7 & 100 & $11.763,6$ \\
\hline
\end{tabular}

Dari hasil perhitungan emisi GRK sektor limbah di kabupaten Karangasem pada Tabel 5 tersebut, selanjutnya dilakukan analisa data spasial dan non spasial untuk mendapatkan pemetaan penghasil emisi GRK per kecamatan di kabupaten Karangasem. Dengan menggunakan ArcView untuk Information Geographic System, pemetaan prosentase sebaran emisi GRK dan sebaran kecamatan penghasil emisi GRK sektor limbah di kabupaten Karangasem adalah seperti ditampilkan pada Gambar $\mathbf{4}$ dan 5.

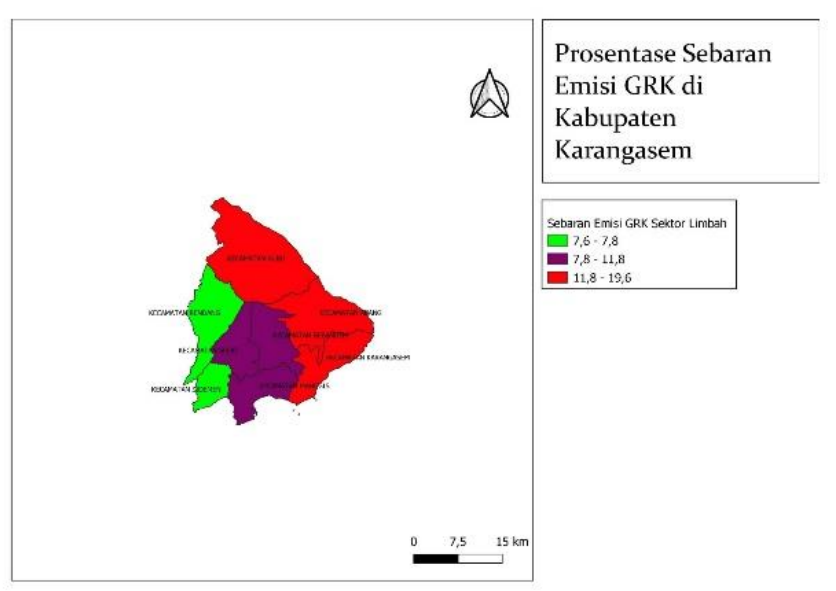

Gambar 4. Pemetaan Prosentase Sebaran Emisi GRK Kab. Karangasem

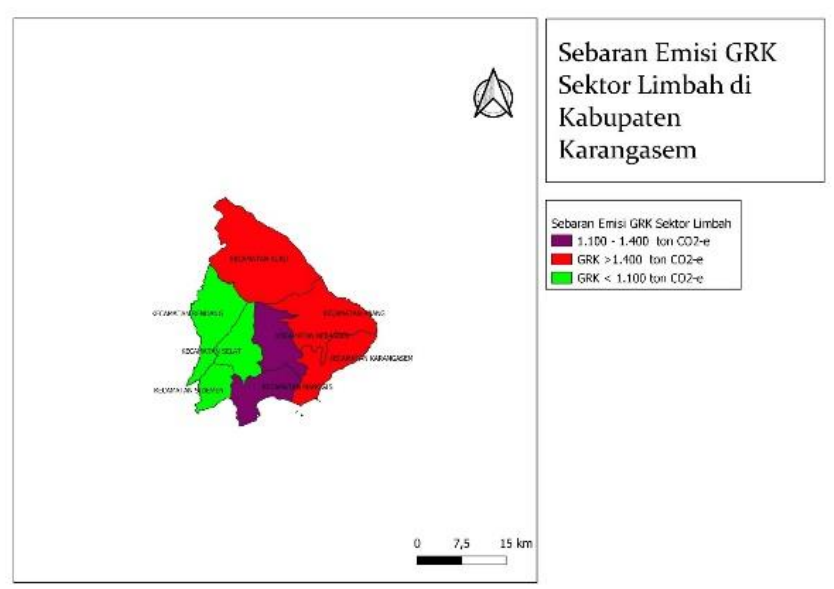

Gambar 5. Pemetaan Sebaran Emisi GRK Sektor Limbah Kab. Karangasem

Dari gambar di atas dapat dilihat bahwa estimasi emisi GRK yang paling tinggi ada di kecamatan Karangasem yaitu sebesar 2.302 ton $\mathrm{CO}_{2}$-e (warna merah), sedangkan estimasi emisi GRK paling rendah ada di kecamatan Sidemen yaitu sebesar 894 ton $\mathrm{CO}_{2}$-e (warna hijau).

Menurut Rahmawati., (2015), tingkat emisi yang dihasilkan sebanding dengan tingkat laju pertumbuhan penduduk. Dengan pertambahan penduduk, maka akan meningkatkan jumlah (sampah) limbah yang dihasilkan, sehingga emisi GRK pun semakin meningkat. Emisi GRK yang dihasilkan dari sektor limbah ini dapat dilihat dari jumlah penduduk dan pertumbuhan ekonomi dan pendapatan dari masing-masing kecamatan. Kecamatan Karangasem merupakan kecamatan yang terletak di tengah kota Karangasem, juga sebagai ibukota Kabupaten Karangasem mempunyai jumlah penduduk paling banyak 
dibandingkan dengan kecamatan lainnya. Dari segi pertumbuhan ekonomi dan pendapatan juga termasuk yang paling tinggi dibandingkan dengan kecamatan lainnya. Jumlah penduduk Kecamatan Karangasem mencapai 23\% persen dari jumlah populasi pendududuk di Kabupaten Karangasem, sedangkan kecamatan Sidemen jumlah penduduknya hanya $8 \%$ dari jumlah penduduk Kabupaten Karangasem.

Dengan adanya penelitian ini, manfaat yang dapat diambil oleh para stakeholder untuk mencari usaha-usaha yang dapat menurunkan emisi GRK (mitigasi). Usaha yang dilakukan agar emisi GRK dapat diturunkan diantaranya yaitu memilah dan memilih sampah-sampah organik dan anorganik. Sampah organik dapat diolah kembali menjadi sesuatu yang bermanfaat seperti pupuk organik, yang dapat dipakai untuk menyuburkan tanaman. Selain itu juga memberikan edukasi kepada masyarakat tentang pengelolaan sampah dengan baik, efek GRK terhadap kehidupan, dan menggalakkan adanya bank sampah dengan program 3R yaitu Reduce, Reuse \& Recycle.

\section{Kesimpulan}

Dari hasil penelitian didapatkan bahwa inventarisasi emisi GRK di Kabupaten Karangasem sebesar 11.763 ton $\mathrm{CO}_{2}$-e, di mana daerah dengan emisi GRK paling tinggi ada di kecamatan Karangasem yaitu sebesar 2.302 ton $\mathrm{CO}_{2}$-e, sedangkan emisi GRK paling rendah ada di kecamatan Sidemen yaitu sebesar 894 ton $\mathrm{CO}_{2}$-e. Dari hasil penelitian yang dilakukan ini dapat diambil kesimpulan bahwa emisi GRK yang dihasilkan dari sektor limbah suatu daerah yang padat penduduknya dapat menghasilkan emisi GRK yang lebih besar dibandingkan dengan yang jumlah penduduknya lebih sedikit. Hal ini dikarenakan timbulan sampah yang ada di daerah yang padat penduduknya lebih besar dibandingkan dengan yang jumlah penduduknya lebih sedikit. Pemetaan daerah penghasil emisi GRK sektor limbah dengan menggunakan ArcView untuk Information Geographic System sangat efektif dilakukan. Dengan adanya pemetaan digital tersebut, diharapkan untuk penanganan/mitigasi dari emisi GRK ini tepat sasaran.

\section{Ucapan Terima Kasih}

Ucapan terima kasih disampaikan kepada ITB STIKOM Bali yang telah memberikan dana penelitian sehingga penelitian ini dapat terlaksana.

\section{Daftar Pustaka}

Badan Pusat Statistik, 2019. Karangasem Dalam Angka 2018. Proyeksi Kependudukan.
Barrera, B. and Hooda, P.S., 2016. Greenhouse Gas Emission of Waste Management Processes and Options: A case Study. Waste Management \& Research. Vol. 34(7). 658-665.

Dinas Lingkungan Hidup Kabupaten Karangasem, 2019. Status Lingkungan Hidup Daerah 2019.

Ebie, Y. and Kobayashi, T., 2014. Development of Emissions Factor for the Decentralized Domestic Wastewater Treatment for the National Greenhouse Gas Inventory. Journal of Water and Environment Technology. Vol.12. 33-41.

Eggleston, H.S., and Tanabe, K., 2006. 2006 IPCC Guidelines for National Greenhouse Gas Inventories: Volume 5- Waste, National Greenhouse Gas Inventories Programme. Japan: IGES.

Elizbarashvili, M., Elizbarashvili, E., Tatishvili, M., Meskhia, R., Kutaladze, N., King, L., Keggenhoff, I., 2017. Georgian Climate Change Under Global Warning Conditions. Annals of Agrarian Science 1-9.

Kementerian Lingkungan Hidup. 2012. Pedoman Penyelenggaraan Inventarisasi Gas Rumah Kaca Nasional. Vol. 4.

MacRae G., Rodic L., 2015. The Weak Link in Waste Management in Tropical Asia? Solid Waste Collection in Bali. Journal of Habitat International. 50. 310-316

Meidiana C. and Gamse T., 2010. Development of Waste Management Practices in Indonesia. European Journal of Scientific Research, Vol 40. EuroJournals Publishing, Inc.

Rachmawaty, V., 2015. Penentuan Faktor Emisi Spesifik Untuk Estimasi Tapak Karbon Dan Pemetaannya Dari Penggunaan Bahan Bakar Di Kabupaten Sidoarjo. Prosiding Seminar Nasional Manajemen Teknologi XXII. Surabaya : Institut Teknologi Sepuluh November.

Supuwiningsih, N.N., 2016. Implementasi Geographic Information System Untuk Pemetaan Lahan Pertanian Kota Denpasar. Jurnal Sistem dan Informatika. Vol. 11. No.1.

Supuwiningsih, N.N., Santosa, A., Januhari, U and Wirahadi, A., 2018. Geographic Information System of Higher Education Mapping in Bali Island Using ArcView. International Journal of Engineering Technologies and Management Research. Vol.5. 167178

Zurbrugg C., Gfrerer M., Ashadi H., Brenner W., Kuper D., 2012. Determinants of Sustainability in Solid Waste Manegement - The Gianyar Waste Recovery Project in Indonesia. Journal of Waste Management. 32. 21262133. 